Syntax Fusion : Jurnal Nasional Indonesia

P-ISSN: $x x x x-x x x x$

E-ISSN : $x x x x-x x x x$

Vol. 1, No. 2, Februari 2021

\title{
PANDANGAN PANCASILA PADA POLITIK INDONESIA DI PERIODE KE-2 MASA PEMERINTAHAN PRESIDEN JOKOWI
}

\author{
Nuradillah, Tri Almuno, LisaAmanda Putri, Merza Karlina, Silvi Rahmadani \\ Universitas Islam Negri Syarif Kasim Riau \\ E-mail: $12010224918 @$ students.uin-suska.ac.id, 12010225055@ students.uin- \\ suska.ac.id,12010221003@students.uin-suska.ac.id, \\ 12010221026@students.uin-suska.ac.id
}

\section{Abstrak}

Negara Indonesia semakin hari semakin memprihatinkan. Tidak hanya merugikan masyarakatnya, tapi juga kalau kita perhatikan system politik yang ada di Indonesia semakin melenceng dari Pancasila, yang mana Pancasila merupakan dasar dari Negara Indonesia itu sendiri. Banyak kebijakan-kebijakan yang diambil oleh aparat pemerintah yang membuat para warganya menjadi resah, bahkan takut akan negaranya sendiri. Juga kelalaian dalam mengambil keputusan yang dilakukan oleh petinggi Negara yang menjadi kerugian terhadap negaranya sendiri. Karya ilmiah ini mengandalkan analisis materi sebagai cara utama dalam menghasilkan argument dan opini di dalam karya ilmiah ini, seperti blog-blog yang di teliti melalui akses internet. Artikel ini berasal dari blog-blog dan website yang dapat dipercaya dan berasal dari media-media yang dapat diakses melalui internet.

Kata Kunci: Pendidikan Pancasila, Presiden Jokowi, Politik Indonesia

\section{Pendahuluan}

Banyak yang telah terjadi di Indonesia selama bapak presiden kita, Joko Widodo, kembali menduduki kursi tertinggi pemerintahan. Nampaknya tugas bapak presiden semakin berat walaupun pada dasarnya setiap presiden memiliki tantangan dan rintangannya sendiri. Mulai dari muculnya wabah Covid-19 dari China, para yang terhormat anggota DPR yang memutuskan RRU Cipta Kerja tanpa adanya campur tangan atau persetujuan rakyat yang malah menyusahkan rakyat kecil dan buruh, keresahan masyarakat Indonesia terhadap kasus tewasnya enam anggota Front Pembela Islam (FPI) yang ditembak polisi, hingga ketidakadilan hukum yang semakin runcing kebawah dan tumpul keatas. Yang mana semua kasus tersebut hanya terjadi dalam waktu yang sangat singkat.

Selama Bapak Jokowi memerintah dapat kita lihat kelebihan dan kekurangannya. Yang pertama, selama memerintah Bapak Jokowi berhasil dalam bidang pembangunan infrastruktur sehingga beliau mendapat julukan bapak infrastruktur. Lalu Bapak Jokowi juga berhasil menjalankan program sosial seperti BPJS, Kartu Indonesai Pintar, Kartu Prakerja, dll. 
Namun ada beberapa catatan selama pemerintahan Bapak Jokowi, secara ekonomi mendapat tantangan yang tidak ringan, perekonomian mengalami penurunan signifikan. Banyak protes dan demo yang telah terjadi namun tidak diindahkan dan tidak diambil tindakan, seperti masalah RUU Cipta Kerja yang belum lama ini menyedot perhatian seluruh lapisan masyarakat Indonesia. Sehingga kepercayaan masyarakat semakin menurun terhadap pemerintah.

Kita tahu bahwa tugas seorang presiden tidaklah mudah, terlebih lagi Negara yang dipimpin oleh sang presiden sangat luas. Namun, seharusnya seorang presiden bertanggung jawab terhadap kesejahteraan rakyatnya, mampu bersikap adil dan bijaksana dengan kebijakannya. Implikasi dari penulisan karya ilmiah ini bertujuan agar politik di Indonesia dapat berjalan sebagaimana semestinya yang telah diatur dalam pancasila sebagai dasar Negara.

\section{Metode Penelitian}

Karya tulis ilmiah ini didapat dari beberapa kasus yang terjadi di Indonesia yang di ambil dari beberapa artikel yang terkait, sehingga dapat menghasilkan argumen di dalam penulisan karya ilmiah ini. Pertama, wabah covid-19 yang melanda Indonesia, yang memicu berbagai konflik yang terjadi di Indonesia, yang diambil dari beberapa kasusus dan artikel yang sedang ramai di beritakan di media tv, surat kabar termasuk melalui internet. Artikel yang di ambil berasal dari situs-situs yang dapat dipercaya. Semua arikel dapat diaskses melalui internet yang merujuk terhadap permasalahan wabah covid-19 yang telah melanda Negara Indonesia dan hampir seluruh Negara yang ada di belahan Dunia.

Kemudian, dilakukan analisis artikel terhadap keresahan masyarakat Indonesia terhadap tewasnya 6 Laskar FPI. Analisis ini dilakukan dengan mengambil beberapa artiket yang terkait. Artikel terkait dapat di akses melalui jejaring internet.

Selain itu, analisis artikel terkait keresahan masyarakat Indosesia terhadap gerakan mahasiswa saat pembuatan UU Cipta Kerja. Analisi ini di ambil dari artikel yang relevan dengan informasi terkait, yang dapat di akses melalui internet.

Selanjutnya, untuk menganalisis keresahan masyarakat Indonesia terhadap perbedaan keadilan di setiap jenjang kehidupan, juga di ambil dari sejumlah artikel. Seperti yang di sebutkan, keresahan masyarakat terhadap status social yang terjadi di Indonesia yang telah terjadi dari waktu ke waktu, menimbulkan berbagai permasalahan yang dapat memperburuk citra diri bangsa Indonesia. Hal ini dapat di pastikan melalui sejumlah artikel, berita, maupun laporan-laporan yang terkait keresahan yang dirasakan oleh masyarakat Indonesia. Semua dokumen dapat di akses melalui internet.

\section{Pembahasan}

1. Wabah Covid-19 Mulai Melanda Indonesia Memicu Berbagai Konflik Yang Terjadi Di Indonesia

Pada awal Maret 2020, diumumkan bahwa Covid telah melanda Indonesia, yang merupakan awalnya virus memasuki Negara ini. Namun, menurut sebagian peneliti para 
ahli Virus Corona mengatakan bahwa Virus ini masuk ke Indonesia di mulai dari bulan Januari. Yang pastinya, Indonesia dilanda pandemi ini pada awal tahun 2020 dan masih belum selesai hingga awal tahun 2021.

Awal mula masuknya Covid ke Indonesia berawal pada tanggal 2 Maret 2020, yang pada tanggal ini pertama kalinya pemerintah mengumumkan dua kasus pasien Indonesia yang positif Covid-19. Akan tetapi, Pakar Epedimologi Universitas Indonesia (UI) Bapak Pandu Riono menyebutkan bahwa, Virus Corona jenis SARS-CoV-2 sebagai penyebab awal mula Covid-19 masuk ke Indonesia sejak awal Januari. "Sejak awal Januari kemungkinan besar virus (SARS-CoV-2) itu sudah masuk ke Indonesia," kata Pandu dalam diskusi daring yang bertajuk "Mobilitas Penduduk dan Covid-19: Implikasi Sosial, Ekonomi dan Politik" Senin (4/5/2020). Hanya saja, identifikasi kasus pertama kali terjadi pada awal Maret yang merupakan trasmisi local dan bukan penularan kasus impor. Masuknya virus tersebut sangat mungkin terjadi melalui pintu-pintu gerbang di wilayah Indonesia. Sejak awal Januari pada saat virus jenis baru ini diumumkan dapat menular anrae manusia, dna sudah menyebar di beberapa Negara selain di Wuhan China, pemerintahan Indonesia lantas tidak langsung menutup akses penerbangan langsung dari Wuhan, yang ada di sekitar enam Bandara, antara lainnya Batam, Jakarta, Denpasar, Manado, Makassar. Pemerintahan merasa sudah cukup dengan melakukan langkahlangkah antisipasi, seperti menggunakan Health Alert Card atau Yellow Card, juga Thermal Scanner untuk mengecek suhu tubuh di atas 38,5 derajat Celcius di pintu masuk dan keluar RI. Akibatnya, menurut Pandu, data laporan kumulatif kasus konfirmasi positif Covid-19 yang setiap hari yang di temukan pemerintah menunjukkan data grafik yang semakin meningkat sejak Maret hingga April yang signifikan di wilayah Sumatra Utara, Bali, Kepulauan Riau, DKI Jakarta, Sulawesi Selatan dan Sulawesi Utara. "Hal ini terlihat dari angka laporan kasus yang terjadi sejak Maret hingga April. Provinsi yang memiliki akses penerbangan langsung ke Wuhan dan dari Wuhan memiliki jumlah kasus konfirmasi yang cukup signifikan," ujar Pandu saat ini, ia juga berkata, yang perlu diperhatikan oleh semua kalangan baik pemerintah dan masyarakat adalah siap untuk berlari maraton, karena pandemic Covid-19 ini akan lebih panjang prosesnya hingga tuntas. "No way back to normal (tidak ada cari kembali ke keadaan normal sebelumnya)," ujar Pandu. Oleh sebab itu, semua elemen perlu mendorong inisiatif Pembatasan Sosial Berbasis Sosial (Lokal) bukan hanya dengan Pembatasan Sosial Berskala Besar (PSBB) saja. Pembatasan social di linkungan masyarakat local dirasa perlu untuk dilakukan sebagai bentuk kewaspadaan. "Komunitas adalah garda terdepan yang selama ini dilupakan, pembatasan social berbasis komunitas lebih berdampak dan membangun solidaritas sosial dan gotong-royong," ujar Pandu.

Berlanjut hingga akhir 2020 wabah Covid-19 masih belum hilang dari tanah air Indonesia, setelah pembatasan dan berbagai protocol kesehatan juga PSBB diberbagai daerah pelosok-pelosok Indonesia, sudah dilaksanakan, tapi Covid-19 masih belum menemukan titik terang obatnya. Sudah banyak aturan yang dilakukan pemerintah untuk mencegah penularannya dengan melarang dan membatasi perkumpulan-perkumpulan 
yang memiliki kemungkinan besar akan tersebarnya virus ini. Namun, tampaknya Covid19 masih enggan untuk meninggalkan kakinya dari Indonesia.

Karna hal tersebut, disepanjang tahun 2020 banyak konflik diantara masyarakat yang terjadi yang disebabkan oleh berbagai hal. Tetapi, prihal ekonomilah yang menjadi masalah utama, disebabkan banyaknya para pegawai yang dengan terpaksa harus di PHK, pedagang yang mesti berhenti berdagang untuk menghindari karamaian, masyarakat yang diminta untuk stay at home, pusat-pusat perbelanjaan yang ditutup sementara, bahkan tempat ibadah pun ditutup. Itu semua merupakan aturan pemerintah untuk menghindari dan mencegah penyebaran Covid-19.

Dari semua kebijakan yang di berlakukan oleh pemerintah itulah timbul berbagai konflik di antara masyarakat. Tidak semua masyarakat dapat menerima dan diam akan peraturan tersebut, sehingga ada yang membangkang dikarenakan mesti terpaksa beraktivitas normal demi tuntunan kehidupan dan kebutuhan. Belum lagi adanya pro dan kontra diantara masyarakat karna ditutupnya pusat perbelanjaan dan lainnya. Belum lagi di tutupnya masjid dan dilarangnya dalam beberapa saat kemarin sholat Jum'at berjamaah di masjid, hingga sholat di masjid dengan jarak $1 \mathrm{M}$ serta segala aktifitas yang mesti dibatasi oleh jarak tersebut. Meski tujuan pemerintah untuk mencegah Covid-19, namun inilah yang menjadi konflik di masyarakat. Masyarakat yang enggan mematuhi aturan protokol kesehatan pun manjadi kendalanya, sehingga pada saat ini pun Cocid-19 masih remaja lela di Negara kita.

Balum konflik lainnya yang terjadi selama masa pandemi ini, yang di poin berikutnya akan kami jelaskan dalam karya ilmiah ini. Berawal dari Covid-19 indonesia memiliki banyak cerita di tahun 2020. Hingga awal tahun 2021 pun cerita ini belum selesai dan masih berlanjut dan bahkan bertambah banyak konflik juga masalah yang yang terjadi. Sampai saat ini masalah vaksin Covid-19 yang didatangkan ke Indonesia menambah konflik dan kericuhan masyarakat Indonesia antara pro dan kontra dengan kebijakan pemerintah tentang wajibnya masyarakat divaksin.

Tidak hanya dikalangan masyarakat di kalangan pemerintahpun ada kelompok pro dan kontra tentang penggunaan vaksin ini. Salah satunya adalah seorang anggota DPR yang sedang viral saat ini, karena menentang keras tidak mau divaksin bahkan rela bayar tenda. Wabah Covid-19 telah menjadi awal bagi pemicu konflik yang terjadi di tahun 2020 pada masyarakat Indonesia. hingga banyaknya kasus kematian para ulama di tahun ini menambah kerisauhan hati tentang apa yang akan terjadi dengan Indonesia dan dunia. Oleh karna itu, mari kita jadikan ini sebagai pelajaran untuk menjalani dan mengintropeksi diri untuk kebaikan dan keselamatan Negara kita juga diri kita hingga dunia ini. Meri kita memperbanyak doa dan lebih mendekatkan diri kepada sang Pencipta, sang Pengatur scenario kehidupan hidup kita Allah Azza Wajallah.

\section{Keresahan Warga Indonesia Terhadap Tewasnya 6 Laskar FPI}

Sejumlah Lembaga Swadaya Masyarakat (LSM) yang tergabung dalam Koalisi Masyarakat Sipil ikut menyampaikan pernyataannya terkait insiden tewasnya enam anggota Front Pembela Islam (FPI) yang ditembak polisi. Koalisi ini menilai ada banyak 
kejanggalan dalam peristiwa tersebut. Perwakilan dari Koalisi Masyarakat Sipil dari LBH Jakarta, Nelson Nikodemus Simamora, menyampaikan bahwa peristiwa tersebut mesti diusut lagi, karena disuga kuat terdapat pelanggaran Hak Asasi Manusia atas peradilan yang adil dan hak hidup warga Negara. Nelson juga memperincikan beberapa kejanggalan tersebut. Salah satunya polisi yang sampai membuntuti FPI hanya karena mendengarkan kabar bahwa adanya pengerahan massa untuk unjuk rasa. "Alasan penembakan juga bersifat umum, yaitu karena penyerangan dari anggota FPI. Jika memang ada senjata api dari pihak FPI mengapa tidak dilumpuhkan saja?" ujar Nelson dalam pernyataan resmi Koalisi Masyarakat Sipil yang dikutip Selasa, 8 Desember 2020. Nelson juga menyingnggu adanya kejanggalan lain, yaitu tak berfungsinya CCTV yang berada di lokasi kejadian. Kemudian, terkait kronologi juga saling bertabrakan antara FPI dan kepolisian. "Tentunya kronologi tersebut tidak bisa ditelan mentah-mentah karena seringkali tidak benar," ujar Nelson.

Dia menjelaskan salah satu kasus pembunuhan terhadap YBD oleh polisi pada tahun 2011 yang ditangani LBH Jakarta. Saat itu, polisi berkilah YBD melawan para petugas sehingga harus ditembak. "Belakangan hasil autopsy menunjukkan bahwa tubuh YBD penuh luka penyiksaan karena diseret dan di pukuli oleh polisi dan pada akhirnya anggota kepolisian yang melakukan pembunuhan dihukum penjara, tapi sangat ringan," katanya. Menurut koalisi, penggunaan senjata api oleh kepolisian mestinya merupakan upaya terakhir yang bersifat melumpuhkan. Hal itu hanya dapat dilakukan oleh anggota Polri saat ia tidak lagi memiliki alternative lain yang beralasan dan masuk akal untuk menghentikan suatu tindakan atau perbuatan pelaku kejahatan atau tersangka. "Koalisi meminta agar dilakukan penyelidikan secara independen yang serius terhadap penembakan yang dilakukan oleh aparat kepolisian, peristiwa ini harus kembali di usut secara trasparan dan akuntabel."ujar Nelson.

Kemudian, ia juga mengingatkan tindakan extrajudicial killing atau pembunuhan di luar putusan pengadilan yang dilakukan aparat kepolisisan terhadap orang-orang yang di duga terlibat kejahatan merupakan sebuah tindakan pelanggaran HAM. Tindakan terebut termasuk ke dalam pelanggaran hokum secara pidana serius. "Orang-orang diduga terlibat kejahatan memiliki hak untuk ditangkap dan dibawa ke muka persidangan dan mendapatkan peradilan yang adil (fair trial) guna membuktikan bahwa apakah tuduhan yang tersampaikan oleh Negara adalah benar," tuturnya. Namun, ada kekhawatiran tindakan brutal tersebut justru tak mendapatkan sanksi. Merujuk pada keadaan selama ini hampir tidak ada penegakan hokum sungguh-sungguh terhadap tindakan extrajudicial killing yang diduga kuat oleh aparat. "Akibatnya terulang kasus-kasus yang serupa. Dalam catatan YLBHI misalnya menemukan sedikitnya 67 orang meninggal sebagai korban tindakan extra-judicial killing pada tahun 2019. Berkaca pada kesus-kasus tahun 2019, mayoritas pelaku adalah para aparat kepolisian yaitu dengan 98,5\% atau 66 kasus dan sisanya (1 kasus) terindikasi militer," ujarnya. Terkait itu, dalam pernyataan resminya, Koalisi Masyarakat Sipil meminta penyelidikan yang serius, transparan dan akuntabel terhadap peristiwa penembakan tersebut. Polisi pun mendesak pemerintah untuk membentuk tim independen yang melibatkan Komnas HAM dan Ombudsman RI 
untuk melakukan penyelidikan dengan serius terkait penembakan tersebut. "Setiap tindakan yang diambil oleh para aparat kepolisian haruslah sesuai dengan ketentuan dan peraturan yang berlaku serta dapat dipertanggungjawabkan," katanya.

Sebelumnya, pihak Polda Metro Jaya yang di suarakan oleh Kapolda Metro Jaya, Inspektur Jendral Polisi Fadli Imran mengetakan, aparat terpaksa melakukan penembakan terseut. Muhammad Abdul Mu'ti (PP) pun meminta kepada pihak masyarakat untuk menahan diri terkait bentroknya polisi dangan pengawal Rizieq Shihab. Sehingga tidak timbul hal-hal yang tak diinginkan. "Masyarakat sebaiknya menahan diri dengan tidak melakukan aksi-aksi yang berpotensi menimbulkan terjadinya kekerasan dan hal-hal yang tidak diinginkan,"ujar Abdul Mu'ti. Berikut ragam tanggapan terkait insiden baku tembak antara pihak polisi dengan sekelompok orang yang diduga laskar FPI dihimpun.

Kepala Staf Kepresidenan Moeldoko memberikan tanggapan terkait peristiwa penembakan terhadap enam anggota laskar FPI di Tol Cikampek. Hal itu menjawab pertanyaan sejumlah anggota Komisi II DPR RI. Dalam rapat bersama Mensesneg, Menseskab, dan Pramono Anung, anggota Komisi II DPR RI Fraksi Gerindra Sodik Mudjahid mempertanyakan informasi yang sudah diterima Istana mengenai kebenaran peristiwa penembakan yang terjadi terhadap 6 anggota laskar FPI tersebut. Namun, Moeldoko mengaku belum bisa memberikan informasi yang sesungguhnya perihal kejadian tersebut. Sebab, ia baru mendengar dari media. Menurut Moeldoko, peristiwa ini harus ditangani dengan hati-hati karna memang cukup sensitif. "Saya beru membaca ini di media dan hal ini memang perlu dikelolah dengan sangat baik dan perlu akurasi yang sangat tinggi, perlu proses, dan saya sudah mengakalturasi situasinya seperti apa karena kejadian ini cukup sensitif,"ujar Moeldoko di Komisi II DPR RI, Senin, 7 Desember 2020.

Kemudian, Moeldoko kembali ditanya oleh anggota Komisi II DPR RI Fraksi PKS Nasir Djamil yang berharap pihak istana untuk membentuk tim pencari fakta. Menjawab hal itu, Moeldeko mengatakan belum bisa mengomentari. Namun, dia berjanji akan menyampaikan pesan itu. "Tentang tim pencari fakta saya belum bisa memberikan komentar, tapi akan kami sampaikan nanti,"jelas Moeldoko.

Menurut Wayan, kostitusi memang dapat menjamin hak asasi setiap warga Negara. Namun dilain sisi, hak asasi setiap orang bukan tanpa batas. Hak asasi warga Negara harus tetap sesuai dengan pertimbangan moral, nilai-nilai agama, keamanan, dan ketertiban umum. Dalam konteks peristiwa ini, kata Wayan, polisi bertindak untuk menjaga ketertiban umum dan keamana. Dia mengajak public untuk memberikan kesempatan ke polisi untuk memberikan penjelasan secara terbuka dan apa adanya kepada semua pihak.

\section{Keresahan Masyarakat Indonesia terhadap Gerakan Mahasiswa Pada Saat Pengesahan UU Cipta Kerja}

Pengesahan RUU Omnibus Law Cipta Kerja menjadi Undang-Undang oleh DPR RI pada Senin (5/10/2020) mendapat protes keras dari banyak kalangan. UU omnibus Law Cipta Kerja dinilai akan banyak merugikan rakyat Indonesia, terutama para 
buruh/pekerja, anti-lingkungan hidup, mengabaikan HAM dan lainnya. Sejumlah lembaga dan para aktivis mengeluarkan Mosi Tidak Percaya kepada para Pemerintah Indonesia dan DPR RI setelah disahkannya UU Cipta Kerja.

Menurut Fraksi Rakyat Indonesia dalam keterangan dalam pres yang diterima Tirto, Selasa (6/10/2020), setiap pasal yang ada dalam RUU Omnibus Law justru menunjukkan Negara mengabaikan hak rakyatnya untuk hidup bermatabat dan justru mempercepat perusakan linkungan. "Sebagian besar dari investasi berjubah percepatan proyek mercusuar Nasional berkedok pembangunan stratagis yang justru membuat masyarakat tidak mampu mempertahankan lahan penghidupannya,"tulis Fraksi Rakyat Indonesia. misalnya, pada proyek strategis Nasional dalam bentuk pembangunan pelabuhan dan bandara baru, yang diantaranya Bandara Kertajati Jawa Barat, Bandara Internasional Kuala Tanjung, Pelabuhan Makassar New Port hingga merambat ke destinasi wisata baru seperti Labuan Bajo yang abai dalam pembangunan berkelanjutan dan menghabisi penghidupan nelayan dan para petani. Contoh lainnya adalah pada Proyek Strategis Nasional dala bentuk pembangunan infrastruktur ketenagalistrikan, seperti PLTU di Batang, Cirebon, dan Indramayu, yang juga menghancurkan lahan petani dan nelayan.

Dijelskan dalam rilisan tersebut bahwa, alih-alih memikirkan nasib para petani dan nelayan yang akan kehilangan sumber penghidupannya, RUU Cipta Kerja justru lebih memfasilitasi keserakahan dan korupsi banyak investor hitam dengan bantuan oligarki. Oligarki sendiri merupakan persekutuan antara pengusaha dan pejabat pemerintah/aparat keamanan yang menggunakan berbagai cara dalam merampas sumber kehidupan masyarakat, dengan dalih pengadaan lahan untuk 'kepentingan umum' tanda adanya indicator yang dapat dipertanggungjawabkan dengan jelas. Niat pembenahan regulai yang digadang-gadangkan dengan RUU Omnibus Cipta Kerja justru akan menciptakan lebih banyak penyumbatan dalam implementasi karena simplifikasi yang dilakukan hanya akan membabat ujung belaka tanpa adanya perencanaan yang terintegrasi dengan agenda pembangunan. UU Omnibus Law Cipta Kerja membuat para pengusaha dapat menikmati Hak Guna Usaha (HUG) langsung dalam 90 tahun-padahal sebelumnya hanya 25/35 tahun dengan perpanjangan 25 tahun jika perusahaan memenuhi syarat. Hal ini akan dapat memperdalam dan perluas konflik agrarian, yang dimana perempuan seringkali mengalami intimidasi dan kekerasan yang berlapis. Omnibus Law ini juga mendukung penindasan dan kecurangan bagi kaum buruh. Jaminan pekerjaan yang layak telah dihilangkan karena outsourcing dan kontrak yang semakin merajalela. Upah dan pesangon pun tidak mendapatkan perlindungan, sehingga akan semakin banyak kesewenang-wenangan yang dapat dilakukan oleh pengusaha nakal. Omnibus Law juga memperburuk perlindungan hak para perempuan buruh. Tidak dikenakan cuti karena haid atau keguguran hanya karena menyebutkan cuti tahunan dan cuti panjang lainnya yang diatur dalam perjanjian kerja, pengaturan atau perjanjian dalam kerja bersama.

Puluhan akademisi dari berbagai universitas yang ada di Indonesia juga menolak dengan keras pengesahan UU Omnibus Law Cipta Kerja. Menurut para akademisi UU ini tidak hanya berisikan pasal-pasal yang bermasalah dimana nilai-nilai konstitusi (UUDNRI Tahun1945) dan Pancasila dilanggar bersamaan tetapi juga cacat dalam 
prosedur pembentukannya. "Aspirasi publik pun kian tak didengarkan, bahkan terus dilakukan pembatasan, seakan tidak lagi mau dan mampu mendengar apa yang menjadi dampak bagi hak-hak dasar para warga,"tulis para akademisi dalam keterangan tertulis yang diterima Tirto, Selasa (6/10/2020). Dengan berlakunya UU Cipta Kerja, maka terdapat beberapa masalah mendasar materi muatan pasal-pasal, yaitu:

Sentralistik rasa Orde Baru. Terdapat hampir 400-san pasal yang manarik kewenangan kepada Presiden melalui pembentukan presiden;

Anti lingkungan hidup. Terdapat pasal-pasal yang mengabaikan semangat perlindungan lingkungan hidup, terutama terhadap pelaksanaan pendekatan berbasis resiko serta semakin terbatasnya partisipasi dalam masyarakat.

Liberalisasi Pertanian. Tidak akan ada lagi perindungan petani ataupun sumberdaya domestic, semakin terbukanya komoditi pertanian impor, serta hapusnya perlindunhan pada lahan-lahan pertanian produktif.

Abai terhadap Hak Asasi Manusia. Pasal-pasal tertentu hanya mengedepankan prinsip semata-mata keuntungan bagi pebisnis, sehingga abai terhadap nilai-nilai hak asasi manusia, terutama terhadap perlindungan dan pemenuhan hak pekerja, hak pekerja perempuan, hak warga dan lain sebagainya.

Mengabaikan prosedur pembentukan UU. Metode 'omnibus law' tidak diatur dalam UU No.12 Tahun 2011 jo UU No.15 Tahun 2019 tentang Pembentukan Peraturan Perundang-undangan

Pengesahan RUU Cipta Kerja juga berpotensi pada krisis HAM. Menanggapi pengesahan RUU Cipta Kerja menjadi Undang-Undang baru saat ini, Direktur Eksekutif Amnesty Internasional Indonesia Usman Hamid mengatakan, pengesahan Ciptaker hari ini menunjukkan kurangnya komitmen antar Pemerintah Indonesia dan anggota DPR RI untuk menegakkan Hak Asasi Manusia. "Mereka yang menentang karena substansi Ciptaker dan prosedur penyusunan UU baru ini sama sekali tidak menjadi pertimbangan dari para pembuat kebijakan. Anggota dewan dan pemerintah, nampaknya lebih memilih untuk mendengar kecil yang diuntungkan oleh peraturan ini. Sementara hak jutaan pekerja ini terancam,"ujarnya. Ia melanjutkan, serikat pekerja dan kelompok masyarakat sipil seharusnya dapat dilibatkan secara terus-menerus dalam pembahasan tentang Undang-Undang ini, karna dari awal anggota merekalah yang akan menanggung langsung akibat serta dampak dari berlakunya Omnibus Law Ciptaker. Peristiwa penting di rapat paripurna hari ini akan memberikan lebih banyak ruang bagi sejumlah perusahaan dan korporasi untuk dapat mengeksplorasikan tenaga kerja, dan akan berujung pada kurannya kepatuhan perusahaan terhadap upah minimum yang terdapat pada UndangUndang. "Belum lagi, perusahaan tidak lagi berkewajiban untuk mengangkat para pekerja kontrak untuk menjadi pegawai tetap. Aturan seperti ini dapat berpotensi menyebabkan perlakuan tidak adil bagi para pekerja, karena mereka akan terus-menerus menjadi pegawai tidak tetap,"kata Usman. "Kami mendesak anggota DPR untuk merevisi aturanaturan yang bermasalah dalam UU Ciptaker. Hak asasi manusia harus menjadi prioritas utama di dalam setiap pengambilan keputusan. Pemerintah juga harus melindungi dan dapat menjamin kebebasan berpendapat dan berekspresi dari mereka yang dirugikan atas 
pengesahan Ciptake ini. Pandemi Covid-19, lagi-lagi tidak boleh dijadikan alasan utama untuk melindungi hak mereka, karna bersuara merupakan satu-satunya jalan untuk didengar bagi mereka yang haknya telah dirampas." "Jangan sampai pengesahan ini menjadikan awal dari krisis hak asasi manusia baru, dimana mereka menentang kebijakan baru dibungkam. Pada tanggal 5 Oktober 2020, DPR RI mengesahkan RUU Cipta Kerja (Omnibus Law) dalam rapat paripurna. Sejak pertama kali diusulkan, Omnibus Cipta Kerja telah menuai kontroversi di kalangan serikat pekerja dan kelompok masyarakat karena mereka memuat pasal-pasal yang dapat mengancam hak pekerja. Proses penyusunan RUU Cipta Kerja dinilai sejumlah kelompok masyarakat kurang trasparan. Pembahasan yang mereka lakukan secara tertutup saat hari libur dan waktu pengesahan yang lebuh cepat dari yang telah dijadwalkan memicu banyaknya protes.

Pembahasan yang dilakukan sejak awal dengan minimnya konsultasi melanggar hak untuk berpartipasi dalam urusan public dan ha katas informasi. Selain iitu, Amnesty menilai bahwa pasal-pasal berikut atau peniadaan pasal-pasal tersebut dapat berpotensi untuk melanggar hak asasi bagi pekerja:

1) Masuknya Pasal 88B yang memberikan kebebasan kepada para pengusaha untuk menentukan unit keluaran yang ditugaskan kepada para pekerja sebaga dasar dari penghitungan upas (system upah per satuan). Tidak ada jaminan bahwa sistembesaran upash per satuan untuk menemukan upah minimum di sector tertentu tidak akan berakhir di bawah upah minimal.

2) Penghapusan Pasal 91 di UU Keternagakerjaan, yang diwaibkan upah yang telah disetujui oleh pengusaha dan pekerja tidak boleh lebih rendah daripada upah minimum sesuai peraturan perundang-undangan.

Apabila persetujuan upah tersebut lebih rendah dari upah minimum yang terdapat dalam peraturan perundang-undangan, maka pengusaha diwajibkan untuk membayar para pekerja yang sesuai dengan standar dari upah minimum dalam peraturan perundangundangan. Jika dilanggar, maka pengusaha akan mendapatkan sanksi.

Menghapus pasal 91 UU Ketenagakerjaan ini akan beujung pada kurangnya kepatuhan pengusaha terhadap upah minimum menerut Undang-Undang. Dengan kata lain, besar kemungkinan besar pengusaha akan memberikan upah yang lebih rendah kepada para pekerja dan tidak melakukan apa-apa lagi, karena kita ada sanksi lain yang harus mereka lakukan.

3) Pencantuman Pasal 59 UU Ketenagakerjaan terkait perubahan status PKWT menjadi PKWTT. Meski demikian, jangka waktu maksimum dalam perjanjian kerja semntara dan jangka waktu perpanjangan maksimum belum diatur secara spesifik seperti dalam UU Ketenagakerjaan, namun dikatakan akan diatur dalam PP.

Catatan: aturan teknis apapun yang dibuat dalam penyususnan Omnibus jangan sampai membebaskan para pengusaha dari kewajiban mereka untuk mengubah status pekerja sementara unruk menjadi pekerja tetap. Hal ini dapat menghilangkan kepastian kerja. 
4) Batasan waktu kerja dalam Pasal 77 ayat (2) masih dapat dikecualikan untuk sector tertentu. Detail skema masa kerja dan sector tertentu yang dimaksud akan dijabarkan lebih lanjut melalui Peraturan Pemerintah (PP)

Ini dapat menimbulkan kekhawatiran akan adanya perbedaan dalam batas waktu kerja bagi sector tertentu dan kompesensinya akan dapat merugikan para pekerja yang berada di sektor-sektor tertentu, karena mereka dapat diminta untuk bekerja lebih lama dan menerima pembayaran untuk lembur yang lebih rendah dibandingkan para pekerja yang berada di sektor lain.

Ia menyebut tindakan massa yang merusak fasilitas umum, membakar, melukai petugas, dan melakukan tindakan penjarahan merupakan tindakan kriminal yang ditindak secara hukum. "Pemerintah akan bersikap dengan tegas dan melakukan proses hukum terhadap semua pelaku dan aktor yang menunggangi rindakan criminal,"kata Mahfud dalam keterangan di Jakarta, Kamis (8/10). Mentri Koordinator Bidang Perekonomian Airlangga Hartato mengklaim bahwa pemerintah mampu membaca gerak demonstrasi yang menurutnya ditunggagi oleh kau elit dan intelektual. Ia berdalih demonstran yang ditunggagi oleh kaum elit karena federasi pekerja atau buruh yang tergolong besar sudah mendukung Omnibus Law Cipta Kerja. Ketua umum Partai Golkar menyatakan bahwasannya tokoh-tokoh intelektual tersebut mempunyai ego sektoral yang cukup besar dan bersembunyi di balik layar sebagai dalang dalam gerakan massa serentak ini. "Pemerintah tahu siapa yang demo itu, kami tahu siapa yang menggerakkannya, siapa yang menjadi sponsornya, dan siapa yang membiayainya. Pemerintah sudah tahu siapa tokoh-tokoh intelek di balik penggerak demo,"kata Airlangga, Kamis (8/10). Kendati demikian, baik Mahfud dan Airlangga sama-sama tidak memberikan bagaimana rincian dan mengaku secara langsung kepada pihak siapa tudingan aktor dan elit penunggang demonstrasi itu ditujukan. Mereka yang mengimbau penolakan seharusnya dilakukan dengan cara yang sesuai dengan hukum. Salah satuny dengan cara mengajukan judicial review atau uji materi UU tersebut ke pihak Mahkamah Konstitusi (MK). Ketegangan aksi tolak UU Ciptaker terjadi di sejumlah wilayah yang berada di tanah air. Mulai dari Medan, Batam, Palembang, Serang, Jakarta, Bekasi, Tangerang, Bandung, Semarang, Yogyakarta, Solo, Surabaya, Palu, hingga Makasar.

Massa buruh dan mahasiswa resah dengan peraturan yang menindas dan memangkas hak-hak warga Negara, terutama para kamu pekerja. Disisi lain, pengusaha besar mendapat keuntungan dengan RUU yang protes penyususnannya tak trasparan tersebut. Hampir sebagian besar aksi di sejumlah wilayah berakhir dengan bentrokan antara massa yang didominasikan oleh mahasiswa dan pelajar dengan aparat kepolisian. Ratusan demonstran pun diamankan dari masing-masing wilayah yang menggelar aksi tersebut. Di Ibu Kota, mahasiswa, pelajar, dan para buruh memusatkan aksi mereka di Istana Negara. Namun, aksi massa tak dapat mencapai depan Istana. Aksi mereka ditahan oleh aparat kepolisian di tiga titik, Patung Kuda Arjuna Wiwaha, persimpangan Harmoni, dan depan Stasiun Gambir. Massa yang terlanjur geram lantaran tak diizinkan menuju depan Istana mencoba untuk menerobos brikade. Mereka melempari petugas dengan batu, 
kayu, dan benda-benda tumpul lainnya, termasuk dengan petasan. Polisi juga membalasnya dengan menyemprotkan para massa dengan water cannon hingga gas air mata. Sejumlah fasilitas umum pun tak luput dari amukan massa, mulai dari halte Trasjakarta hingga Pos Kepolisian. Sudah tercatat tiga Pos Kepolisian yang terbakar. Sementara itu, terdapat dua halte bus Trasjakarta yang terbakar, diantaranya Bundaran HI dan Sarinah. Gurbernur DKI Jakarta Anies Baswedan sudah mengkalkulasikan biaya yang diperlukan untuk memperbaiki kerusakan yang ditimbulkan dengan sekitar anggaran Rp 25 miliar. Namun, halte permanen tidak bisa segera diperbaiki. Penangan terdekat sementara, DKI akan membangun halte. Sedangkan Polda Metro Jaya mengaku telah meringkus hampir 1.000 orang yang diduga menjadi perusuh dalam aksi demo tolak UU Ciptaker yang berada di Ibu Kota. Para terduga perusuh tersebut disinyalir dengan sengaja menunggagi aksi demo yang dilakukan oleh para buruh dan mahasiswa.

Disisi lain, Komisi Nasional HAM meminta kepada pemerintah agar cepat merespon demo terhadap penolakan UU Omnibus Law Cipta Kerja yang eskalasinya terus meningkat. Komisioner Komnas HAM Beka Ulang Hapsari mengatakan, respons pemerintah penting dilakukan, karena demonstrasi berlangsung di tengah masalah pandemi virus Corona. DPR mengesahkan Omnibus Law Cipta Kerja pada Rapat Paripurna, Senin (5/10) lalu. Poin-poin yang ada di dalam UU sapujagat tersebut banyak manuai protes karena dapat dinilai memangkas hak buruh dan berpotensi memicu kerusakan pada lingkungan. Ketua DPR Puan Maharani berharap untuk Omnibus Law Cipta Kerja agar dapat membangun ekosistem berusaha di Indonesia yang lebih baik dan mempercepat kemajuan Indonesia. Puan juga mempersilahkan bilamana masyarakat tak sepakat dan mengajukan uji materi ke MK. Sementara, Tenaga Ahli Kedeputian Kantor Staf Presiden (KSP) Donny Gahral Adian menyebutkan bahwa pemerintah pusat belum mempertimbangkan opsi menerbitkan Peraturan Pemerintah Pengganti Undang-Undang (Perpu) Cipta Kerja. Donny mengatakan upaya Omnibus Law Cipta Kerja adalah melalui gugatan uji materi ke MK.

\section{Keresahan Warga Indonesia Terhadap Perbedaan Keadilan di Setiap Jenjang Kehidupan}

Indonesia merupakan Negara hukum. Sebagai Negara hukum, tentunya penegakan hukum yang tidak memihak telah diatur dalam Undang-Undang Dasar 1945 Pasal 27 ayat (1) UUD 1945 yang dimana semua orang diperlakukan sama di depan umum. Untuk menerapkan hal Negara hukum, Indonesia sendiri dituntut untuk dapat menerapkan prinsip-prinsip yang dijalankan oleh Negara hukum. Setiap manusia memiliki hak untuk memperoleh keadilan, baik hal tersebut dri masyarakat maupun dari Negara. Seperti yang tercantum dalam Pancasila, sila ke-5 yang berbunyi: "Keadilan bagi seluruh rakyat Indonesia". hal ini sangat jelas bahwa seluruh rakyat Indonesia berhak untuk mendapatkan keadilan tanpa terkecuali. Tidak pandang bulu, entah itu dari kalangan pejabat, rakyat kecil, orang kaya atau miskin. Tujuan hukum itu sendiri adalah memberikan keadilan kepada setiap orang. 
Namun, dalam prakteknya hal ini sudah tidak berlaku lagi di Indonesia. Hukum di Indonesia sekarang dinilai belum mampu memberikan keadilan kepada masyarakat yang tertindas maupun di tindas. Justru sebaliknya, hukum sekarang menjadi alat bagi pemegang kekuasan untuk dapat bertindak semena-mena. Saat ini hukum di Indonesia yang di untungkan dan menjadi pemenangnya merupakan para oaring-orang yang memiliki kekuasaan, yang mempunyai banyak uang walaupun mereka melanggar karna, yang memiliki uang banyak pasti aman dari gangguan hukum sekalipun hukum Negara dilanggar. Orang biasa yang ketahuan melakukan tindakan kecil langsung ditangkap dan dijebloskan ke dalam penjara. Sedangkan seorang pejabat Negara yang melakukan tindakan korupsi sejumlah uang yang bahkan mencapai angka puluhan miliyar milik Negara itu sendiri dapat dengan mudah berkeliaran dengan bebasnya. Karena hukuman itu cenderung hanya untuk dan berlaku terhadap orang miskin yang tidak mampu dan seolah-olah tidak berlaku bagi orang kaya, sehingga tidak sedikit orang yang menilai bahwa hukum di Indonesia dapat dibeli dengan uang dan kekuasaan. Beberapa tahun belakangan ini, hukum di Negara Indonesia semakin buruk. Hukum sekarang seakanakan bukan lagi dasar bangsa Indonesia. ada banyak pengakuan informal dari masyarakat bahwa karena hukum dapat dibeli, maka aparat penegak hukum tidak dapat diharapkan untuk melakukan penegakan hukum secara menyeluruh dan adil.

Ketidakadilan hukum di Indonesia telah memperburuk citra diri bangsa, sekaligus menjajah bangsa sendiri. Kita seharusnya merasa malu dengan moral bangsa yang begitu naïf. Indonesia bahkan belum dapat dibilang sepenuhnya merdeka, karna bangsa ini masih terbelenggu oleh ketidakadilan yang dilakukan pemerintahannya sendiri. Hukum dan keadilan menjadi hal yang mahal untuk didapat di Negara ini.

Banyak terjadi kasus-kasus ketidakadilan hukum yang terjadi. Salah satunya merupakan Kasus Ketidakadilan humu yang dialami oleh seorang nenek yang bernama Asyani (63) ini benar-benar menggambarkan pepatah yang popular di kalangan masyarakat,"hukum di negeri ini tumpul ke atas, tajam ke bawah". Asyani dilaporkan oleh sejumlah polisi hutan ke Polsek Jatibanteng pada 4 Juli 2014. Nenek yang memiliki empat orang anak itu kemudian di tahan pada 15 Desember 2014. Asyani deseret ke Pengadilan Negeri Situbondo Jawa timur dengan tuduhan mencuri 38 papan kayu jati di lahan Perhutanio di Desa Jatibanteng, Situbondo. Asyani merupakan seorang tukang pijat. Dia didakwah dengan Pasal 12 huruf d jucto Pasal 83 ayat (1) huruf a UndangUndang Nomor 18 Tahun 2013 tentang Pencegahan dan Pemberantasan Perusakan.

Selain kasus nenek Asyani masih ada kasus lainnya. Bandingkan nasib ibu Minasih, beliau dituntut 7 tahun penjara Cuma gara-gara mencuri buah randu milik perusahaan. Bandingkan dengan Seorang Mafia Pajak Gayus Tambunan beliau dihukum 7 tahun penjara namun masih bisa keluar masuk penjara dengan bebas bahkan sampai berlibur ke Bali.

Semakin kentara jika membandingkan penanganan kasus kecelakaan maut anak Menko Perekonomian Hatta Rajasa, Rasyid Rajasa dengan kasus loncatnya mahasiswi Universitas Indonesia Annisa Azward dari angkot yang terjadi hari Rabu tanggal 6 Februari 2013. Jika menengok kasus Jamal tentu tak seberat dengan Rasyid. Putra bungsu 
Hatta Rajasa itu pada 1 Januari 2013 silam, mengemudikan mobil BMW dengan kecepatan tinggi lalu menabrak mobil Luxio di Tol Jagorawi. Rasyid sudah menjadi tersangka, tapi diistimewakan. Rasyid dijerat pasal 283, 287, dan 310 UU Lalu Lintas Nomor 22 Tahun 2009, dengan ancaman hukuman 6 tahun penjara.

Kemudian kasus lainnya adalah penabrakan pejalan kaki di trotoar oleh pengemudi mobil Daihatsu Xenia bernama Aftriani Susanti. Setelah diselidiki, penyebab penabrakan tersebut diketahui bahwa sang pengemudi berada dalam pengaruh alkohol dan sabu-sabu. Namun, yang menakjubkan ialah ia hanya dikenakan vonis 6 tahun penjara, padahal kesalahannya berlipat ganda, yaitu membunuh orang, merusak trotoar, mengonsumsi sabu-sabu, dan mengemudi dalam pengaruh alkohol.

Masih banyak kasus-kasus ketidakadilan hukum yang terjadi di negara kita. kasus-kasus diatas merupakan contoh kecilnya saja. Itulah fenomena yang terjadi di bangsa ini. mereka para koruptor yang mencuri uang Negara bermilyar-milyar, dihukum seringan-ringannya. Bahkan tak jarang terjadi dibeberapa kasus korupsi, para koruptor malah dibebaskan dengan uang jaminan atau hanya menjadi tahanan rumah. Kemanakah hukum Negara kita yang katanya tidak memihak? mungkin itu semua hanya kata-kata, hukum di Negara kita belum bisa dikatakan baik.

Dari beberapa kasus-kasus yang ada, dengan demikian, belajar dari fakta sejarah, ketegasan dalam penegakan hukum merupakan kunci penting untuk mengatasi berbagai problem. selain itu solusi yang dapat dilakukan Pertama, melakukan reformasi birokrasi agar ia segera bersih dari sistem, prosedur, dan pejabat-pejabat yang korup. Kedua, secepatnya memutus hubungan dengan persoalan-persoalan KKN yang diwariskan oleh Orde Baru agar kita keluar dari blokade yang mengepung dari berbagai lini.pemutusan hubungan ini bisa dilakukan dengan cara radikan (amputasi tanpa pandang bulu) dan bisa juga dilakukan dengan cara kompromi (ampuni dan rekonsiliasi dengan permakluman) yang kemudian ditindaklanjuti dengan tindakan-tindakan tegas. Ketiga, membangun sistem rekrutmen politik yang demokratis dan terbuka melalui pemilu dengan sistem proporsional terbuka.

\section{Penutup}

Penulisan Artikel ini memberikan tinjauan kritis terhadap pandangan Pancasila terhadap politik Indonesia pada priode ke-2 masa pemerintahan Preside Jokowi, focus utamanya terhadap wabah Covid-19 yang mulai melanda Indonesia memicu berbagai konflik yang terjadi di Indonesia, keresahan masyarakat Indonesia terhadap tewasnya 6 laskar FPI, keresahan masyarakat Indonesia terhadap gerakan mahasiswa saat UU Cipta Kerja, dan keresahan masyarakat Indonesia terhadap perbedaan dalam keadilan di setiap jenjang kehidupan.

Dalam beberapa tahun ini banyak berbagai masalah datang silih berganti melanda Negara Indonesia, mulai dari peristiwa wabah Covid-19 yang dari awal tahun 2020 sampai sekarang belum adanya titik terang, dilanjutkan dengan 6 orang laskar FPI yang tewas ditembak oleh kepolisian, yang mengakibatkan keresahan semakin dirasakan oleh masyarakat Indonesia, ditambah dengan pengesahan UU Cipta Kerja yang merugikan 
bagi kaum buruh dan petani sehingga menimbulkan ketegangan antara para mahasiswa yang melakukan demo dengan pemerintah, yang dibantu oleh aparat Kepolisian, hingga kesenjangan sosial dan ketidakadilan yang makin dirasakan oleh masyarakat Indonesia.

Untuk itu diharapkan kedepannya Indonesia lebih bisa mengatasi dan mengantisipasi setiap tindakan yang dilakukan oleh Pemerintah agar tidak membuat para masyarakatnya menjadi resah terhadap kepemimpinannya, maupun pihak masyarakat yang lebih menahan emosi atas segala tindakan yang akan dilakukan.

\section{Bibliografi}

"Memahami Pancasila di Zaman Now." Kompas, 05 Februari 2018. https://edukasi.kompas.com/read/2018/02/05/19450091/memahamipancasila-dizaman-now diunduh pada 26 Oktober 2018.

Artikel dari website Direktorat Jenderal Pembelajaran dan Kemahasiswaan Kemenristekdikti https://belmawa.ristekdikti.go.id/wpcontent/uploads/2017/12/Paparan-NarsumMateri-Radikalisme-Dikti2.0.pptx diunduh pada 01 November 2019.

"Organisasi Papua Merdeka yang menuntut pemisahan Papua dari Indonesia, apa dan siapa mereka?." BBC Indonesia, 13 Desember 2018. https://www.bbc.com/indonesia/indonesia-46539502 diunduh pada 26 Juli 2019.

"Bina Penghina Pancasila , Polres Malang Dinilai Pancasilais." Jawa Pos, 26 Januari 2018. https://www.jawapos.com/jpg-today/26/01/2018/binapenghina-pancasilapolres-malang-dinilai-pancasilais/ diunduh pada 27 Juli 2019.

“Akhir Damai Penolakan Slamet di Dusun Karet Bantul." 2019. Liputan 6, 02 April 2019. https://www.liputan6.com/regional/read/3932221/akhirdamai-penolakan-slametdi-dusun-karet-bantul diunduh 28 Juli 2019. "Penasihat Kepala BPIP: Rekomendasi DPR, PIP jadi BPIP." CNN Indonesia, 17 Maret 2018. https://www.youtube.com/watch?v=IyB3i6F0bMM diunduh 30 September 2019.

"Mahfud: BPIP Dibentuk Karena Ada Ancaman terhadap Ideologi Pancasila." DetikNews, 31 Mei 2018. https://news.detik.com/berita/d 704046816/mahfudbpip-dibentuk-karena-ada-ancaman-terhadapideologi-pancasila diunduh pada 27 Maret 2019.

"Presiden Teken Perpres, Badan Pembinaan Ideologi Pancasila." 2018. Situs Resmi Sekretariat Negara, 6 Maret 2018. https://setkab.go.id/presiden-teken-perpres-ukppip-jadi-badanpembinaan-ideologi-pancasila/) diunduh pada 25 November 2019.

“Jokowi Lantik Megawati Jadi Ketua Dewan Pengarah BPIP.” Kompas, 21 Maret 2018. nasional.kompas.com/read/2018/03/21/17134921/kamisjokowi-lantik-megawatijadi-ketua-dewan-pengarah-bpip diunduh pada 28 November 2019.

"BPIP dan BNPT Tandatangani Nota Kesepahaman." Situs Resmi BPIP, 04 November 2019. http://www.bpip.go.id/informasi/bpip-dan-bnpttandatangani-nota- 